\title{
The Association Between the Risk of Hypertensive Disorders of Pregnancy and Folic Acid: A Systematic Review and Meta-Analysis
}

\author{
Yahui Yu ${ }^{1,2,3}$, Ximu Sun ${ }^{1,2,3}$, Xinrui Wang ${ }^{1,2,3}$, and Xin Feng ${ }^{1,2}$ \\ ${ }^{1}$ Department of Pharmacy, Beijing Obstetrics and Gynecology Hospital, Capital Medical University, Beijing, China; ${ }^{2}$ \\ Department of Pharmacy, Beijing Maternal and Child Health Care Hospital, Beijing, China; ${ }^{3}$ Department of Clinical \\ Pharmacology, College of Pharmaceutical Sciences, Capital Medical University, Beijing, China
}

\begin{abstract}
Corresponding Author: Xin Feng, Department of Pharmacy, Beijing Obstetrics and Gynecology Hospital, Capital Medical University, No.17, Qi He Lou Street, Dongcheng District, Beijing, China; TEL: (+86) 10 52275218; Fax: (+86) 10 52275218; email: fengxin1115@126.com
\end{abstract}

Received, January 12, 2021; Revised, April 4, 2021; Accepted, April 5, 2021; Published, April 19, 2021

\begin{abstract}
Purpose: Although folic acid (FA) supplementation has been shown to reduce general cardiovascular risks, its impact on hypertensive disorders of pregnancy (HDP) is unclear. We performed a systematic review and meta-analysis to clarify the association between FA and the risk of HDP (pre-eclampsia (PE) and gestational hypertension (GH)). Methods: PubMed, EmBase, and Cochrane Library were searched up to June 18, 2020, stratified by type of disease, initiation time of FA, form of FA and pre-conception Body Mass Index (BMI). The quality assessment of included studies was evaluated using Newcastle-Ottawa Scale (NOS) for cohort studies and Cochrane Collaboration's Risk of Bias Assessment Tool for randomized controlled trials (RCTs). Between-study heterogeneity was quantified using Cochran's Q-statistic and $I^{2}$ statistics. Sensitivity analysis was performed by excluding the studies one by one, and publication bias was analyzed using funnel plots. Results: Twenty studies with 359041 patients were identified for inclusion in the meta-analysis which included 3 RCTs and 17 cohort studies. Pooled estimates showed RR of 0.83 (95\%CI 0.74-0.93, $\mathrm{P}=0.0008$ ) for association between low dose FA (LD-FA) and the risk of PE, but LD-FA was not associated with GH (RR 1.05, 95\% CI 0.97-1.13, P=0.20). In addition, the results of subgroup analysis showed that post-conception LD-FA had a $31 \%$ decreased risk of PE (RR 0.69, 95\% CI 0.59-0.80, P<0.00001), and LD-FA in patients with pre-conception BMI $<25 \mathrm{~kg} / \mathrm{m}^{2}$ had a $32 \%$ decreased risk of PE (RR $0.68,95 \%$ CI 0.56-0.81, P<0.0001) Conclusions: LD-FA significantly decreased the risk of PE but not GH, and postconception LD-FA and pre-conception $\mathrm{BMI}<25 \mathrm{~kg} / \mathrm{m}^{2}$ were considered as protective factors to reduce the risk of PE.
\end{abstract}

\section{INTRODUCTION}

Hypertensive disorders of pregnancy (HDP) accounts for $16 \%$ of maternal deaths and is also associated with severe morbidity, long term disability and death among both mothers and their babies (1). This group of diseases includes preeclampsia (PE) and eclampsia, gestational hypertension (GH) and chronic hypertension. In addition, some evidence showed that women with HDP were at increased risk of developing chronic kidney disease, cardiovascular disease (CVD) and even cardiovascular mortality (2-3). Therefore, effective prevention and treatment of HDP is critical. At present, several clinical practice guidelines have clearly recommended that aspirin could be used for the prevention of HDP in high-risk pregnant women (1-3). A meta-analysis which with focus on the general cardiovascular health indicated a $10 \%$ lower risk of stroke and a $4 \%$ lower risk of overall CVD with folic acid (FA) supplementation (4). However, studies investigating the use of FA to prevent HDP have yielded inconsistent results. Currently, the relationship between FA and HDP has been widely studied (5-27), and five meta-analyses with inconsistent results have been published (28-32). Two meta-analyses demonstrated that FA was not associated with the risk of GH or PE (28-29). Two demonstrated that multivitamin containing FA (VitFA) could significantly lower GH or PE risk (30-31). And one showed no significant difference between FA alone and Vit-FA in reducing PE (32). The latest retrieval deadline for these meta-analyses was Aug. 2017. Since then, six other studies have been published. In addition, FA initiation time, and preconception Body Mass Index (BMI) were used as grouping conditions in some cohort studies, so these 
factors are an important opportunity for subgroup analysis of meta-analysis.

The purpose of this study was to perform a systematic review and meta-analysis to clarify the association between FA and the risk of HDP.

\section{MATERIALS AND METHODS}

\section{Search Strategy}

We conducted a comprehensive search in PubMed, EmBase, and Cochrane Library from the date of their inception up to June 18, 2020. The search terms were composed of the following: "folic acid", "vitamin b9", "preeclampsia", "pregnancy induced hypertension", "gestational hypertension", "hypertensive disorders of pregnancy". To identify potential publications, we also examined the references of relevant reviews and meta-analysis. The details of the search strategy were summarized in the Appendix 1.

\section{Study Selection}

Inclusion criteria: (1) population-based studies, including cohort studies, case-control studies, and randomized controlled trials (RCTs). (2) the exposure factor is FA or Vit-FA. (3) the outcome is $\mathrm{GH}$ or PE. (4) the written language is English.

Exclusion criteria: (1) not original studies (e.g., reviews, meta-analysis, commentaries, case reports, editorials and letters). (2) conducted in animals. (3) studies without control group (comparison between different dose or FA alone and Vit-FA) (4) studies lack the necessary data (e.g., non-full text articles, unpublished trials).

\section{Data Extraction}

Two investigators (YHY, XMS) assessed the eligibility of retrieved articles and extracted relevant data from each eligible study using a standardized form independently. From included studies, the following information were extracted: study characteristics (first author's name, year of publication, study design, range of years in the studies, country), participants' characteristics (population size, gestational age at recruitment, age, pre-conception BMI, FA dose, the initiation time of FA (pre-conception or post-conception), type of disease (GH or PE), the HRs, RRs, ORs with 95\% CIs of $\mathrm{GH} / \mathrm{PE}$ adjusted for confounders.

\section{Outcomes}

The primary outcome was the risk of PE. The secondary outcome was the risk of GH.

\section{Quality Assessment}

The methodological quality assessment of included studies was independently assessed by two reviewers (YHY, XMS) according to the Newcastle-Ottawa Scale (NOS) and the Cochrane Collaboration's Risk of Bias Assessment Tool. Two reviewers (XRW, XF) resolved the disagreements, and the final consensus was reached by all four reviewers. For cohort studies, the NOS includes three aspects with a nine-point scale: selection of study population, compatibility of the study groups, and ascertainment of outcomes, and the scores of $0-3,4-6$, and 7-9 were interpreted as low, moderate, or high quality. For RCTs, the Cochrane Collaboration's Tool includes six aspects with seven items: random sequence generation, allocation concealment, blinding of participants and personnel, blinding of outcome assessment, incomplete outcome data, selective reporting, and other bias.

\section{Statistical analysis}

This meta-analysis was conducted by Review Manager for Windows (version 5.3) using the generic inverse variance method. Between-study heterogeneity was quantified using Cochran's Qstatistic and $I^{2}$ statistics and a value of $P<0.10$ or an $I^{2}>50 \%$ was considered statistically significant for heterogeneity among studies. The random-effect model was used if it was significant; otherwise, the fixed-effect model was acceptable. Subgroup analyses were performed according to the type of disease (GH or PE), initiation time of FA (preconception or post-conception), form of FA (Vit-FA or FA alone) and pre-conception BMI (BMI $<25$ $\mathrm{kg} / \mathrm{m}^{2}$ or $\mathrm{BMI} \geq 25 \mathrm{~kg} / \mathrm{m}^{2}$ ), respectively. The sensitivity analysis was conducted by excluding the studies one by one to evaluate the stability of results without estimation bias from individual study. The funnel plots were used to evaluate publication bias qualitatively.

\section{RESULTS}

\section{Search Results}

The search strategy yielded 1294 abstracts. Manual searching identified 4 additional articles. A total of 1269 articles were excluded after de-duplicating and the review of abstracts, leaving 29 studies for fulltext review for eligibility. Overall, 20 studies with 359041 patients were identified that were eligible for inclusion in the meta-analysis. ${ }^{5-24}$ The whole literature search process was summarized in the Figure 1. 


\section{Study Characteristics}

This meta-analysis included 3 RCTs and 17 cohort studies. Characteristics of the 20 included studies in the meta-analysis were presented in Table 1 and

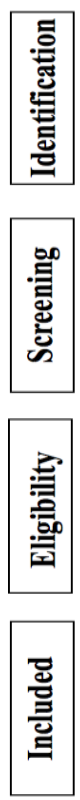

Table 2. These studies were published between 2002 and 2020. The study populations ranged from 215 to 193554 participants, with a total number of 359041. There were 12 studies that didn't clearly describe the

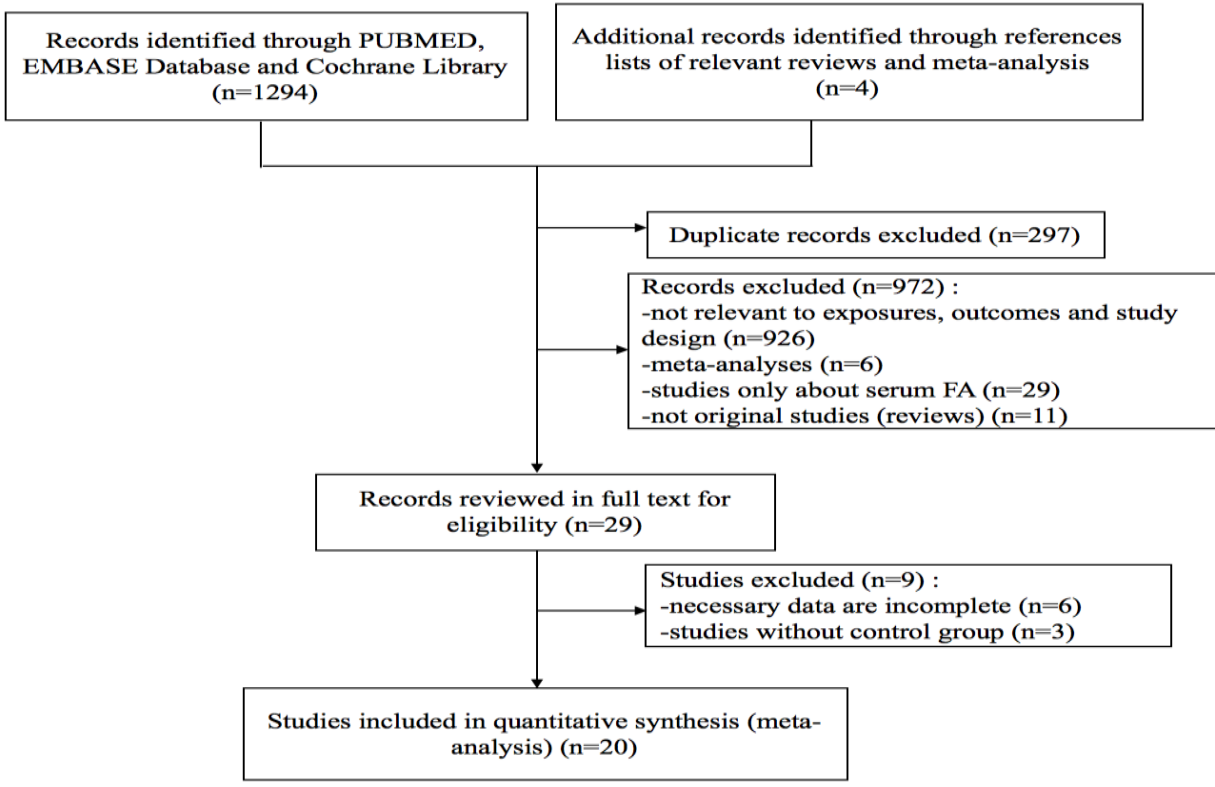

Figure 1. Folic acid and the risk of Hypertensive Disorders of Pregnancy flow diagram.

initiation time of FA, 4 studies that began taking FA in post-conception period, and 1 study in preconception period. FA alone or Vit-FA was $0.2-1 \mathrm{mg}$ in most studies, except for 3 RCTs which used high dose (4-5mg) FA. The ascertainment of GH/PE were from medical records and self-report, and there are 14 studies evaluating the risk of PE alone and 6 studies evaluating the risk of both GH and PE. In addition, 5 articles performed a subgroup analysis based on the pre-conception BMI. The ORs, RRs and HRs in 18 studies were adjusted based on the potential confounders. The 20 studies were undertaken in different countries, including the USA $(\mathrm{n}=6)$, Canada $(\mathrm{n}=4)$, China $(\mathrm{n}=4)$, Denmark $(\mathrm{n}=2)$, Netherlands $(n=1)$, the UK $(n=1)$, South Korea $(n=1)$ and Australia $(n=1)$.

\section{Quality Assessment}

NOS was used to assess the risk of bias for 17 cohort studies. All cohort studies were given a score of 7-9 stars, representing the high quality of studies. The six cohort studies had scores of 7-8 for the reason that FA and HDP were identified only based on selfreports. The results of this quality assessment were summarized in Appendix 2-Table A. Cochrane Collaboration's Tool was used to assess the risk of bias for 3 RCTs, and only random sequence generation of Charles 2005 was unclear. ${ }^{6}$ Appendix 3 -Figure 1 and Figure 2 showed the results of the risk of bias assessment, representing that all RCTs were of high quality.

\section{High Dose (HD)-FA and the Risk of PE}

Three studies compared risk of PE with HD-FA. The results showed that HD-FA was not associated with PE (3 studies, RR 1.11, 95\% CI 0.75-1.62, $P=0.61$; Figure 2). No obvious asymmetry was found in the funnel plot (Appendix 4-Figure 1), which indicated that publication bias was unlikely in the analysis. The results of sensitivity analysis showed no substantial modification of the estimates after exclusion of individual study one by one.

Low Dose (LD)-FA and the Risk of HDP(GH/PE) Eighteen studies compared risk of HDP with LD-FA. Stratification by GH and PE showed that LD-FA significantly decreased the risk of PE (18 studies, RR $0.83,95 \%$ CI $0.74-0.93, P=0.0008$, Figure 3 ), but was not associated with GH (6 studies, RR $1.05,95 \%$ CI $0.97-1.13, \quad P=0.20 ; \quad$ Figure 3 ). No obvious asymmetry was found in the funnel plot (Appendix 4-Figure 2), which indicated that publication bias was unlikely in the analysis. The results of sensitivity analysis showed that the association between LD-FA and decreased risk of PE in PE subgroup was reliable.

\section{Pre-conception or Post-conception LD-FA and the Risk of PE}

11 studies with 23 results compared the association between peri-conception LD-FA and the risk of PE. According to the initiation time (Pre-conception or Post-conception), a subgroup analysis was 
Risk Ratio

Study or Subgroup log[Risk Ratio] SE Weight IV, Random, $95 \% \mathrm{Cl}$

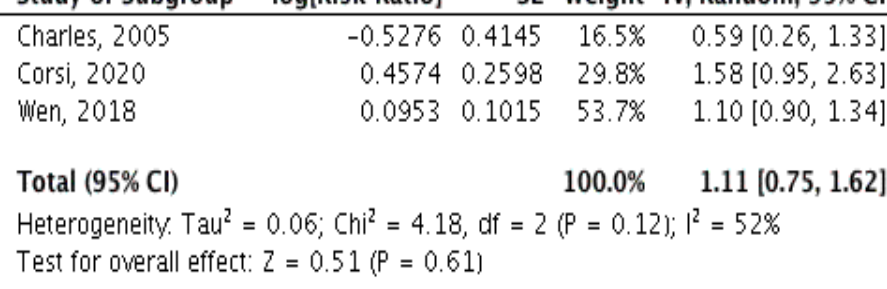

Figure 2. Forest plot for High Dose Folic Acid and the risk of Hypertensive Disorders of Pregnancy
Risk Ratio

IV, Random, 95\% Cl

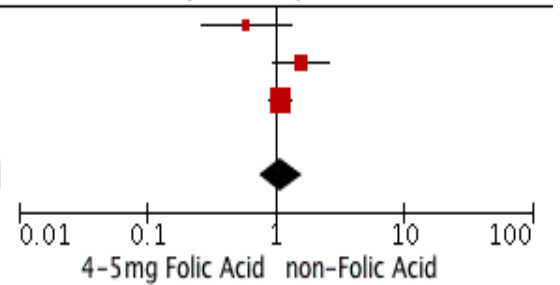

\begin{tabular}{|c|c|c|c|c|c|c|}
\hline \multirow{2}{*}{\multicolumn{2}{|c|}{$\begin{array}{l}\text { Study or Subgroup log[Risk } \\
1.2 .1 \text { Gestational Hypertension }\end{array}$}} & SE & Weight & $\begin{array}{l}\text { Risk Ratio } \\
\text { IV, Random, } 95 \% \mathrm{CI}\end{array}$ & \multicolumn{2}{|c|}{$\begin{array}{c}\text { Risk Ratio } \\
\text { IV, Random, } 95 \% \mathrm{CI}\end{array}$} \\
\hline & & & & & & \\
\hline Hernández-Díaz, 2002 & -0.6349 & 0.2037 & $2.0 \%$ & $0.53[0.36,0.79]$ & & \\
\hline Hernández-Díaz, 2002 & -0.4943 & 0.2536 & $1.4 \%$ & $0.61[0.37,1.00]$ & & \\
\hline Ocampo, 2017 & -0.2744 & 0.6635 & $0.3 \%$ & $0.76[0.21,2.79]$ & & \\
\hline Ocampo, 2017 & -0.0943 & 0.6185 & $0.3 \%$ & $0.91[0.27,3.06]$ & & \\
\hline OKEN, 2007 & 0.0198 & 0.0174 & $6.6 \%$ & $1.02[0.99,1.06]$ & & - \\
\hline $\mathrm{Li}, 2020$ & 0.0392 & 0.0875 & $4.7 \%$ & $1.04[0.88,1.23]$ & & \\
\hline Li, 2020 & 0.0392 & 0.0904 & $4.6 \%$ & $1.04[0.87,1.24]$ & & \\
\hline Li, 2013 & 0.0862 & 0.0234 & $6.6 \%$ & $1.09[1.04,1.14]$ & & - \\
\hline Timmermans, 2011 & 0.0953 & 0.2264 & $1.7 \%$ & $1.10[0.71,1.71]$ & & \\
\hline $\mathrm{Li}, 2020$ & 0.1222 & 0.1053 & 4. $1 \%$ & $1.13[0.92,1.39]$ & & \\
\hline $\mathrm{Li}, 2020$ & 0.2776 & 0.1113 & $3.9 \%$ & $1.32[1.06,1.64]$ & & \\
\hline $\begin{array}{l}\text { Timmermans, } 2011 \\
\text { Subtotal (95\% CI) }\end{array}$ & 0.3365 & 0.2161 & $\begin{array}{l}1.8 \% \\
37.9 \%\end{array}$ & $1.40[0.92,2.14]$ & & 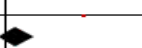 \\
\hline \multicolumn{6}{|c|}{$\begin{array}{l}\text { Heterogeneity. } \mathrm{Tau}^{2}=0.01 ; \mathrm{Chi}^{2}=27.92, \mathrm{df}=11(\mathrm{P}=0.003) ; \mathrm{I}^{2}=61 \% \\
\text { Test for overall effect: } z=1.27(\mathrm{P}=0.20)\end{array}$} & \\
\hline \multicolumn{7}{|l|}{ 1.2.2 Preeclampsia } \\
\hline Kim, 2014 & -1.3093 & 0.5443 & $0.4 \%$ & $0.27[0.09,0.78]$ & & \\
\hline Vanderlelie, 2014 & -1.1087 & 0.4282 & $0.6 \%$ & $0.33[0.14,0.76]$ & & \\
\hline Wen, 2008 & -0.9943 & 0.3641 & $0.8 \%$ & $0.37[0.18,0.76]$ & & \\
\hline Ocampo, 2017 & -0.8675 & 0.4645 & $0.5 \%$ & $0.42[0.17,1.04]$ & & - \\
\hline Vanderlelie, 2014 & -0.8675 & 0.5153 & $0.4 \%$ & $0.42[0.15,1.15]$ & & \\
\hline Charles, 2005 & -0.7765 & 0.423 & $0.6 \%$ & $0.46[0.20,1.05]$ & & - \\
\hline wen, 2008 & -0.7765 & 0.5364 & $0.4 \%$ & $0.46[0.16,1.32]$ & & \\
\hline Bodnar, 2006 & -0.5978 & 0.2776 & $1.2 \%$ & $0.55[0.32,0.95]$ & & \\
\hline Ocampo, 2017 & -0.5978 & 0.4947 & $0.4 \%$ & $0.55[0.21,1.45]$ & & \\
\hline Liu, 2015 & -0.5798 & 0.1184 & $3.7 \%$ & $0.56[0.44,0.71]$ & & \\
\hline wen, 2016 & -0.5447 & 0.2879 & $1.2 \%$ & $0.58[0.33,1.02]$ & & \\
\hline wang, 2015 & -0.4943 & 0.1798 & $2.3 \%$ & $0.61[0.43,0.87]$ & & \\
\hline Hernández-Díaz, 2002 & -0.462 & 0.4195 & $0.6 \%$ & $0.63[0.28,1.43]$ & & \\
\hline Catov, 2009 & -0.3011 & 0.1428 & $3.1 \%$ & $0.74[0.56,0.98]$ & & \\
\hline Wen, 2016 & -0.2744 & 0.3837 & $0.7 \%$ & $0.76[0.36,1.61]$ & & \\
\hline Martinussen, 2015 & -0.2231 & 0.1768 & $2.4 \%$ & $0.80[0.57,1.13]$ & & - \\
\hline Timmermans, 2011 & -0.2231 & 0.2627 & $1.3 \%$ & $0.80[0.48,1.34]$ & & 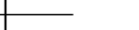 \\
\hline Catov, 2009 & -0.1278 & 0.1153 & $3.8 \%$ & $0.88[0.70,1.10]$ & & — \\
\hline Timmermans, 2011 & -0.1054 & 0.2438 & $1.5 \%$ & $0.90[0.56,1.45]$ & & \\
\hline Catov, 2009 & -0.0513 & 0.2818 & $1.2 \%$ & $0.95[0.55,1.65]$ & & \\
\hline Catov, 2011 & -0.0513 & 0.0772 & $5.0 \%$ & $0.95[0.82,1.11]$ & & - \\
\hline OKEN, 2007 & -0.0408 & 0.0373 & $6.3 \%$ & $0.96[0.89,1.03]$ & & \\
\hline Catov, 2009 & -0.0202 & 0.3432 & $0.9 \%$ & $0.98[0.50,1.92]$ & & \\
\hline Bukowski, 2009 & 0.0296 & 0.0913 & $4.5 \%$ & $1.03[0.86,1.23]$ & & - \\
\hline $\mathrm{Li}, 2020$ & 0.0296 & 0.2831 & $1.2 \%$ & $1.03[0.59,1.79]$ & & \\
\hline Bukowski, 2009 & 0.0488 & 0.1103 & $3.9 \%$ & $1.05[0.85,1.30]$ & & $=$ \\
\hline Catov, 2011 & 0.077 & 0.1352 & $3.3 \%$ & $1.08[0.83,1.41]$ & & \\
\hline Martinussen, 2015 & 0.0953 & 0.3196 & $1.0 \%$ & $1.10[0.59,2.06]$ & & \\
\hline $\mathrm{Li}, 2013$ & 0.1906 & 0.0423 & $6.1 \%$ & $1.21[1.11,1.31]$ & & 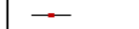 \\
\hline $\mathrm{Li}, 2020$ & 0.2231 & 0.2826 & $1.2 \%$ & $1.25[0.72,2.17]$ & & \\
\hline $\mathrm{Li}, 2020$ & 0.2546 & 0.3408 & $0.9 \%$ & $1.29[0.66,2.52]$ & & \\
\hline \multirow{3}{*}{\multicolumn{5}{|c|}{$\begin{array}{l}\text { Subtotal (95\% CI) } \\
\text { Heterogeneity. } \mathrm{Tau}^{2}=0.04 ; \mathrm{Chi}^{2}=106.36 \text {, df }=31\left(\mathrm{P}<0.00001 \% ; \mathrm{I}^{2}=71 \%\right. \\
\text { Test for overall effect: } \mathrm{Z}=3.34(\mathrm{P}=0.0008)\end{array}$}} & & \\
\hline & & & & & & \\
\hline & & & & & & \\
\hline \multicolumn{5}{|c|}{ Total $(95 \% \mathrm{Cl}) \quad 100.0 \% \quad 0.93[0.87,0.99]$} & & \\
\hline \multicolumn{5}{|c|}{$\begin{array}{l}\text { Heterogeneity. } \mathrm{Tau}^{2}=0.02 ; \mathrm{Chi}^{2}=142.22, \mathrm{df}=43(\mathrm{P}<0.00001) ; \mathrm{I}^{2}=70 \% \\
\text { Test for owerall effect: } \mathrm{Z}=2.29(\mathrm{P}=0.02 \mathrm{~J} \\
\text { Test for subgroup differences: } \mathrm{Chi}^{2}=12.06, \mathrm{df}=1\left(\mathrm{P}=0.0005 \mathrm{~J}, \mathrm{I}^{2}=91.7 \%\right.\end{array}$} & Folic Acid & $1 \frac{1}{1} \frac{1}{1}$ \\
\hline
\end{tabular}

Figure 3. Forest plot for Low Dose Folic Acid and the risk of Hypertensive Disorders of Pregnancy in subgroup analysis by type of disease (Gestational hypertension or Pre-eclampsia)

performed. The results showed that pre-conception LD-FA was not associated with the PE ( 9 studies, RR 0.92 , 95\% CI 0.84-1.02, $\mathrm{P}=0.12$, Figure 4 ), but postconception LD-FA had a $31 \%$ decreased risk of PE (9 studies, RR 0.69, 95\%CI 0.59-0.80, $P<0.00001$; Figure 4). No obvious asymmetry was found in the funnel plot (Appendix 4-Figure 3), which indicated that publication bias was unlikely in the analysis. The results of sensitivity analysis showed that the association between post-conception LD-FA and the decreased risk of PE was reliable.

\section{LD-FA in patients with pre-conception $B M I<25$} $\mathrm{kg} / \mathrm{m}^{2}$ or $B M I \geq 25 \mathrm{~kg} / \mathrm{m}^{2}$ and the Risk of PE

According to the pre-conception BMI $(\mathrm{BMI}<25$ $\mathrm{kg} / \mathrm{m}^{2}$ or $\mathrm{BMI} \geq 25 \mathrm{~kg} / \mathrm{m}^{2}$ ), a subgroup analysis was performed to compare the association between LD- 


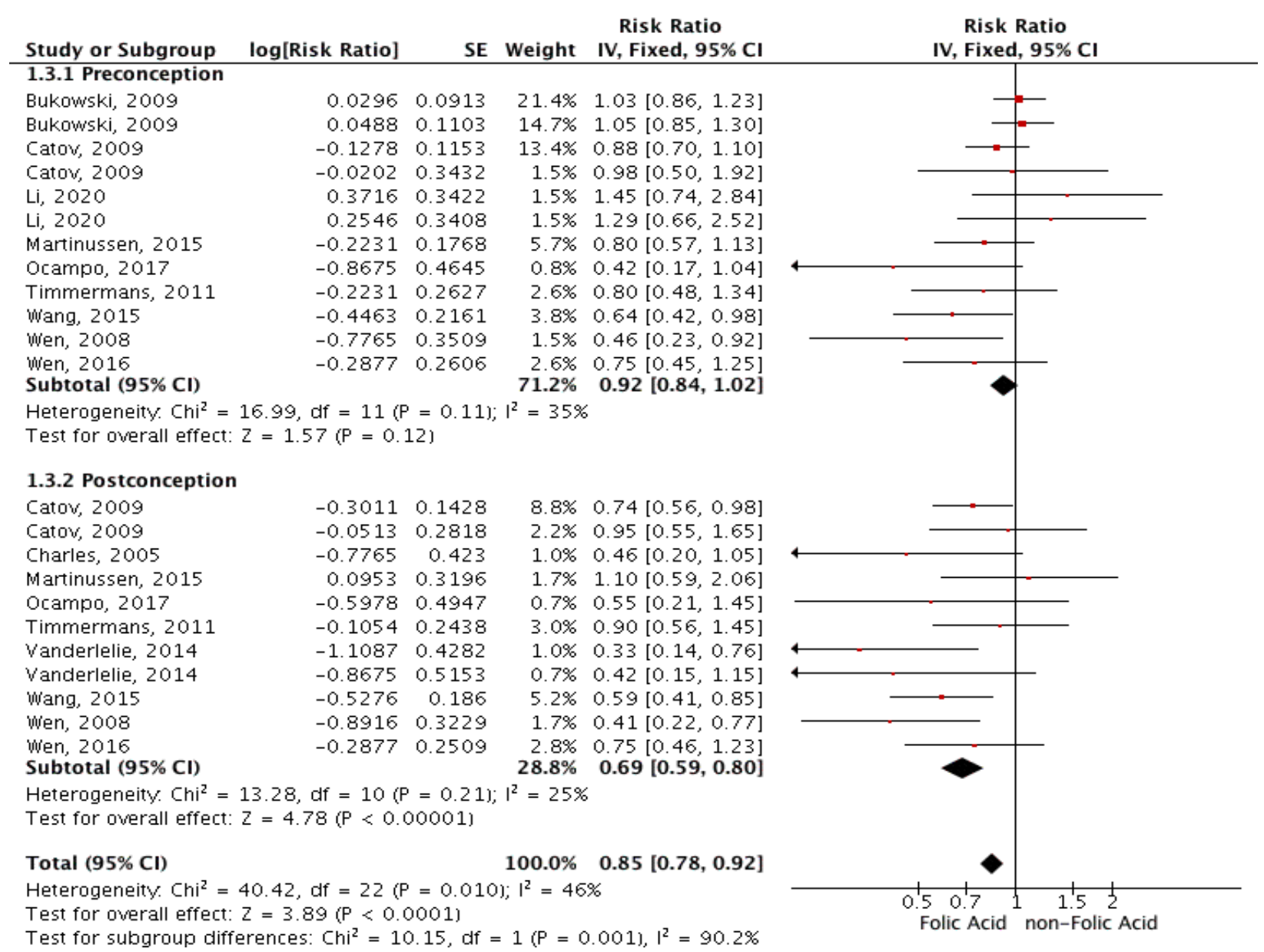

Figure 4. Forest plot for Low Dose Folic Acid and the risk of Hypertensive Disorders of Pregnancy in subgroup analysis by initiation time (pre-conception or post-conception)

FA and the risk of PE in 4 studies with 14 results. The results showed that LD-FA in patients with preconception $\mathrm{BMI}<25 \mathrm{~kg} / \mathrm{m}^{2}$ had a $32 \%$ decreased risk of PE (4 studies, RR 0.68 , 95\%CI 0.56-0.81, $\mathrm{P}<0.0001$, Figure 5), but no difference was found in patients with pre-conception $\mathrm{BMI} \geq 25 \mathrm{~kg} / \mathrm{m}^{2}$ (4 studies, RR 0.87, 95\%CI 0.71-1.05, $P=0.14$; Figure $5)$. No obvious asymmetry was found in the funnel plot (Appendix 4-Figure 4), which indicated that publication bias was unlikely in the analysis. The results of sensitivity analysis showed that the association between LD-FA and the decreased risk of $\mathrm{PE}$ in pre-conception $\mathrm{BMI}<25 \mathrm{~kg} / \mathrm{m}^{2}$ subgroup was reliable.

\section{FA alone or Vit-FA and the Risk of PE}

According to the form of FA (FA alone or Vit-FA), a subgroup analysis was performed in 8 studies with 13 results. The results showed that Vit-FA significantly decreased the risk of PE (4 studies, RR 0.82 , 95\% CI 0.68-0.98, $\mathrm{P}=0.03$, Figure 6 ), but no reduction in $\mathrm{PE}$ was found in patients receiving $\mathrm{FA}$ alone (7 studies, RR 0.86, 95\%CI 0.65-1.13, $P=0.27$; Figure 6). Asymmetry can be seen in the funnel plot

(Appendix 4-Figure 5), especially the Vit-FA subgroup, indicating that there is publication bias in the analysis. In addition, after excluding Bodnar 2006, $P$-value changed to 0.86 (RR, 95\%CI 0.73 1.01, $P=0.06)$, after excluding Catov 2009, $P$-value changed to 0.83 (RR, 95\% CI 0.66-1.04, $P=0.10$ ), which indicated that the association between Vit-FA and the decreased risk of PE was not reliable.

\section{DISCUSSION}

Our meta-analysis of 20 studies involving 359041 patients found that LD-FA was associated with the decreased risk of PE but not GH. In addition, postconception LD-FA and pre-conception $\mathrm{BMI}<25$ $\mathrm{kg} / \mathrm{m}^{2}$ were considered as protective factors to reduce the risk of PE.

Some studies of the association between FA and the risk of GH or PE have shown a potential protective effect $(5,7,9,11,15-17,19)$, and Wen 


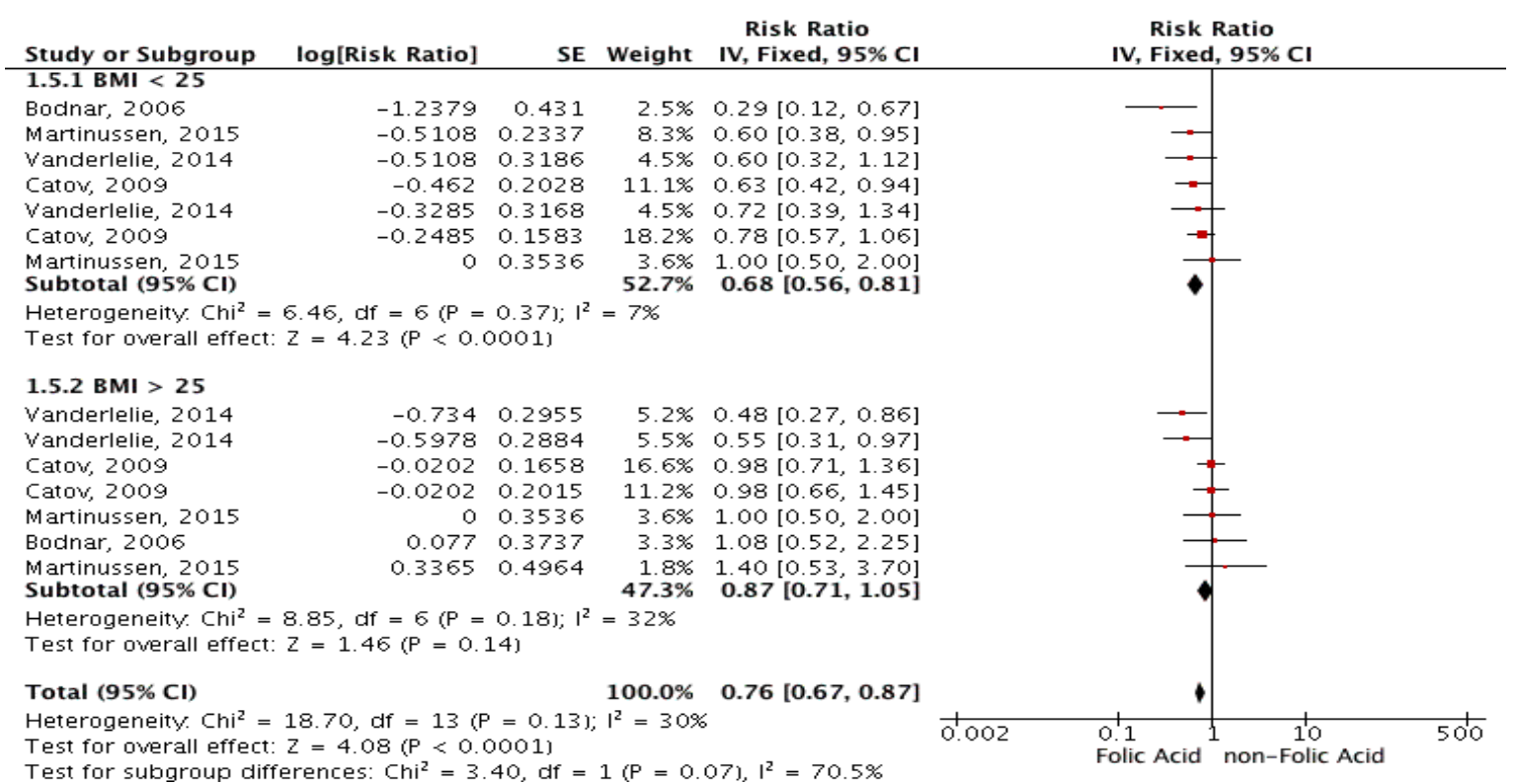

Figure 5. Forest plot for Low Dose Folic Acid and the risk of Hypertensive Disorders of Pregnancy in subgroup analysis by pre-conception Body Mass Index $\left(\mathrm{BMI}<25 \mathrm{~kg} / \mathrm{m}^{2}\right.$ or $\left.\mathrm{BMI} \geq 25 \mathrm{~kg} / \mathrm{m}^{2}\right)$

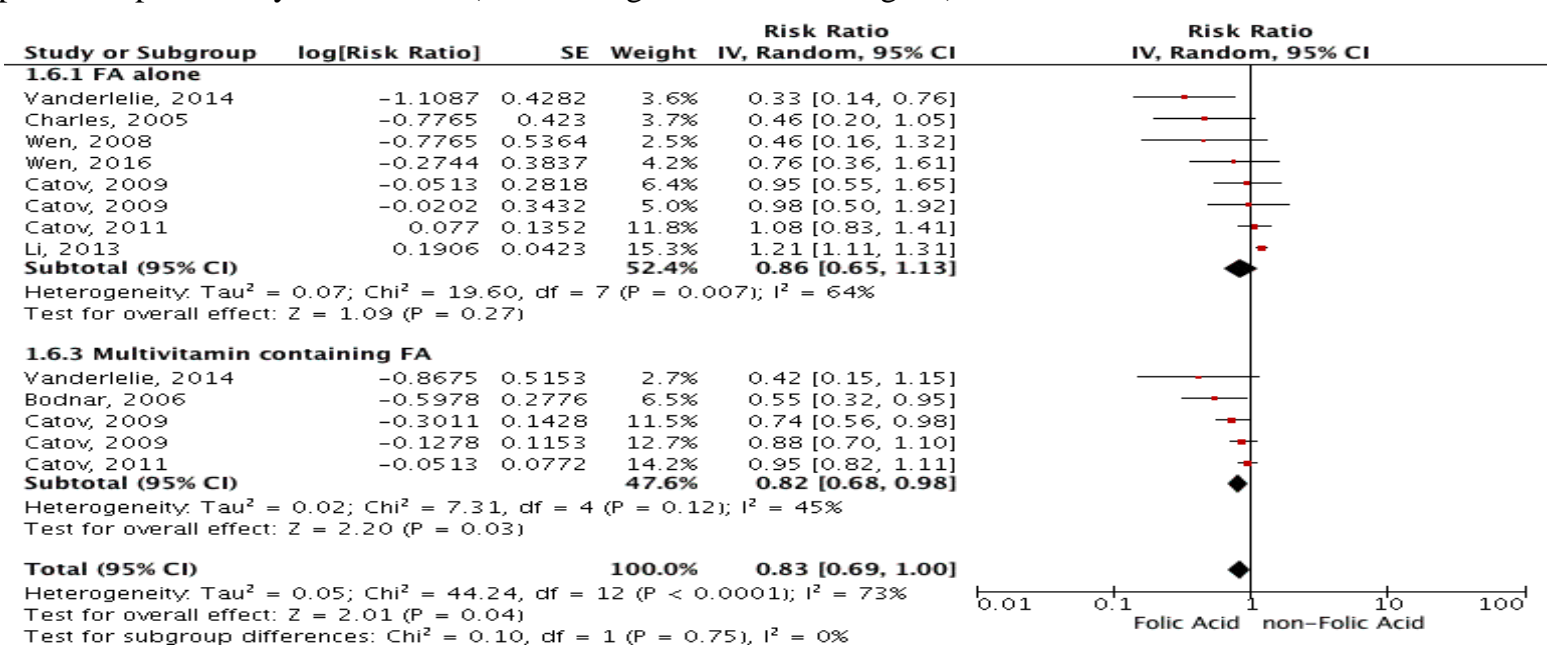

Figure 6. Forest plot for Low Dose Folic Acid and the risk of Hypertensive Disorders of Pregnancy in subgroup analysis by form of Folic Acid (Multivitamin containing FA or FA alone)

(22) has shown that maternal exposure to FA antagonists appears to increase the risk of placentamediated adverse outcomes of pregnancy (33). It has been proved that elevated plasma homocysteine (Hcy) level was associated with increased risk for various forms of CVD, and it was also significantly elevated in women with PE (34). The possible pathogenic mechanisms involve damage of endothelial cell, reduction of vascular flexibility, changes in the hemostatic process and promotion of the development of inflammation. The elevated Hcy may arise from genetic defect of blood pressure, the altered process of DNA and protein synthesis of placental growth and development, and the imbalance between FA and vitamin $\mathrm{B}_{12}(24)$. methylenetetrahydrofolate reductase (MTHFR) or insufficient intake of FA (35-36). In the prevention and treatment of CVD, in addition to reducing Hcy levels, FA could also increase nitric oxide synthase (NOS) coupling and nitric oxide (NO) bioavailability to improve vascular health and function which are independent of the Hcy-lowering effect (37). However, two studies have shown that FA supplementation might be associated with the increased risk of $\mathrm{GH}$ or PE $(14,24)$. There are some possible explanations, including the increased red cell blood mass which is correlated with elevated

In the late first trimester or early second trimester, placental growth and development reach the peak. Thus, FA supplementation in this period 
Table 1. The characteristics of included studies

\begin{tabular}{|c|c|c|c|c|c|c|c|}
\hline Author, year & $\begin{array}{l}\text { Design, years, } \\
\text { country }\end{array}$ & Characteristics & $\begin{array}{c}\text { FA initiation } \\
\text { time }\end{array}$ & Dose & $\begin{array}{l}\text { Gestational } \\
\text { age (weeks) } \\
\quad \text { at } \\
\text { recruitment }\end{array}$ & Age(years) & $\begin{array}{l}\text { Pre-conception } \\
\text { BMI }(k g / m 2)\end{array}$ \\
\hline $\mathrm{Li}, 2020$ & $\begin{array}{l}\text { Prospective } \\
\text { cohort, 2013-, } \\
\text { China }\end{array}$ & $\begin{array}{l}4853 \text { participants from the Tongji Maternal and } \\
\text { Child Health Cohort with information on } \\
\text { periconceptional FA supplement use and } \\
\text { diagnosis of GH/PE, } 1161 \text { and } 161 \text { women were } \\
\text { diagnosed with GH and PE }\end{array}$ & $\begin{array}{l}\text { pre-conception } \\
\text { or post- } \\
\text { conception }\end{array}$ & $\begin{array}{l}\text { at least } \\
0.4 \mathrm{mg} / \text { day }\end{array}$ & NR & $28.6(\mathrm{SD} 3.4)$ & 20.6 (SD 2.6) \\
\hline Corsi, 2020 & $\begin{array}{l}\text { Randomized } \\
\text { Controlled Trial, } \\
2011-2015 \\
\text { Canada }\end{array}$ & $\begin{array}{l}428 \text { women pregnant with twins who were aged } \\
18 \text { y or older, between } 8 \text { and } 16 \text { completed weeks' } \\
\text { gestation and had } \\
\text { at least one high risk factor for PE }\end{array}$ & post-conception & 4mg/day & $\begin{array}{l}13.8(\mathrm{SD} \\
1.9, \mathrm{FA}) \\
14.0(\mathrm{SD} \\
1.8, \text { non-FA) }\end{array}$ & $\begin{array}{l}31.5 \text { (SD5.2, FA) } \\
31.4 \text { (SD5.0,non-FA) }\end{array}$ & NR \\
\hline Wen, 2018 & $\begin{array}{l}\text { Randomized } \\
\text { Controlled Trial, } \\
2011-2015, \\
\text { Canada } \\
\end{array}$ & $\begin{array}{l}2301 \text { pregnant women with at least one high risk } \\
\text { factor for PE ( } 1144 \text { to the FA group and } 1157 \text { to } \\
\text { the placebo group) }\end{array}$ & post-conception & 4mg/day & 14 (SD 1.9) & 31 (SD 5.4) & $\begin{array}{l}34(\mathrm{SD} 8.6, \mathrm{FA}) \\
34(\mathrm{SD} 13, \text { non- } \\
\text { FA) }\end{array}$ \\
\hline $\begin{array}{l}\text { Ocampo, } \\
2017\end{array}$ & $\begin{array}{l}\text { Retrospective } \\
\text { cohort, 2004- } \\
\text { 2014, USA }\end{array}$ & $\begin{array}{l}3247 \text { participants recruited from the Mother- } \\
\text { ToBaby (MTB) network, } 2697 \text { were early users } \\
\text { and } 471 \text { were late users of FA-containing } \\
\text { supplements, and } 79 \text { were nonusers during their } \\
\text { pregnancy }\end{array}$ & $\begin{array}{l}\text { pre-conception } \\
\text { or post- } \\
\text { conception }\end{array}$ & NR & NR & $\begin{array}{l}32.3 \text { (SD 4.7, pre- } \\
\text { conception-FA) } \\
30.4 \text { (SD 6.0, post- } \\
\text { conception-FA) } \\
32.8 \text { (SD 5.6,non- } \\
\text { FA) }\end{array}$ & $\begin{array}{l}24.5 \text { (SD 5.2, pre- } \\
\text { conception FA) } \\
25.9 \text { (SD 6.1, } \\
\text { post-conception } \\
\text { FA) } \\
25.7 \text { (SD 7.3,non- } \\
\text { FA) }\end{array}$ \\
\hline Wen, 2016 & $\begin{array}{l}\text { Prospective } \\
\text { cohort, 2002- } \\
\text { 2008, Canada }\end{array}$ & $\begin{array}{l}7669 \text { pregnant women who were less than } 20 \\
\text { weeks gestational age in Ottawa, ON and } \\
\text { Kingston, ON, Canada }\end{array}$ & $\begin{array}{l}\text { pre-conception } \\
\text { or post- } \\
\text { conception }\end{array}$ & $\begin{array}{l}\text { most } 1.0 \mathrm{mg} \text { or } \\
\text { higher }\end{array}$ & NR & NR & $\mathrm{NR}$ \\
\hline Liu, 2015 & $\begin{array}{l}\text { Prospective } \\
\text { cohort, 2010- } \\
\text { 2012, China } \\
\end{array}$ & $\begin{array}{l}10179 \text { women ( } 7864 \text { FA supplement, } 2315 \text { non- } \\
\text { FA) with live singleton births in Lanzhou, China }\end{array}$ & $\begin{array}{l}\text { pre-conception } \\
\text { or post- } \\
\text { conception }\end{array}$ & NR & NR & NR & NR \\
\hline Wang, 2015 & $\begin{array}{l}\text { Prospective } \\
\text { cohort, 2010- } \\
\text { 2012, China }\end{array}$ & $\begin{array}{l}10041 \text { pregnant women with gestational age } \geqslant 20 \\
\text { weeks and aged } 18 \text { years or older, without } \\
\text { chronic hypertension, gestational hypertension } \\
\text { and mental illness }\end{array}$ & $\begin{array}{l}\text { pre-conception } \\
\text { or post- } \\
\text { conception }\end{array}$ & NR & NR & NR & NR \\
\hline $\begin{array}{l}\text { Martinussen, } \\
2015\end{array}$ & $\begin{array}{l}\text { Prospective } \\
\text { cohort,1996- } \\
\text { 2000, USA }\end{array}$ & $\begin{array}{l}3647 \text { women (1710 from the AIP study and } 1937 \\
\text { from the NIP study) who were followed from the } \\
\text { first trimester of pregnancy in New England, } \\
\text { USA }\end{array}$ & $\begin{array}{l}\text { pre-conception } \\
\text { or post- } \\
\text { conception }\end{array}$ & NR & NR & NR & Table 1 continues... \\
\hline
\end{tabular}


J Pharm Pharm Sci (www.cspsCanada.org) 24, 174 - 190, 2021

\begin{tabular}{|c|c|c|c|c|c|c|c|}
\hline Kim, 2014 & $\begin{array}{l}\text { Retrospective } \\
\text { cohort, 2009- } \\
\text { 2010, South } \\
\text { Korea }\end{array}$ & $\begin{array}{l}215 \text { participants with singleton pregnancies at the } \\
\text { Korea University Anam Hospital }\end{array}$ & NR & NR & NR & $\begin{array}{l}31.9 \text { (SD 3.9,FA) } \\
31.3 \text { (SD 4.7,non- } \\
\text { FA) }\end{array}$ & NR \\
\hline $\begin{array}{l}\text { Vanderlelie, } \\
2014\end{array}$ & $\begin{array}{l}\text { Prospective } \\
\text { cohort, 2006- } \\
\text { 2011, Australia }\end{array}$ & $\begin{array}{l}2619 \text { mothers with live births in Queensland, } \\
\text { Australia }\end{array}$ & post-conception & most $0.8 \mathrm{mg} /$ day & NR & NR & NR \\
\hline $\mathrm{Li}, 2013$ & $\begin{array}{l}\text { Retrospective } \\
\text { cohort, 1993- } \\
\text { 1995, China }\end{array}$ & $\begin{array}{l}193554 \text { women in } 2 \text { southern provinces (Jiangsu } \\
\text { Province and Zhejiang Province) }\end{array}$ & $\begin{array}{l}\text { pre-conception } \\
\text { or post- } \\
\text { conception }\end{array}$ & $0.4 \mathrm{mg} /$ day & NR & $\begin{array}{l}24.21 \text { (SD 2.47,FA) } \\
25.54 \text { (SD 3.77,non- } \\
\text { FA) }\end{array}$ & $\begin{array}{l}20.37 \text { (SD } \\
2.29, \mathrm{FA}) \\
20.89 \text { (SD } \\
2.49, \text { non-FA) }\end{array}$ \\
\hline $\begin{array}{l}\text { Timmermans, } \\
2011\end{array}$ & $\begin{array}{l}\text { Prospective } \\
\text { cohort, 2002- } \\
\text { 2006, } \\
\text { Netherlands }\end{array}$ & $\begin{array}{l}9778 \text { women at early pregnancy in Rotterdam, the } \\
\text { Netherlands }\end{array}$ & $\begin{array}{l}\text { pre-conception } \\
\text { or post- } \\
\text { conception }\end{array}$ & $0.4-0.5 \mathrm{mg} /$ day & NR & $\begin{array}{l}29.8 \text { (IQR 19.7-39.0, } \\
\text { post-conception) } \\
31.6 \text { (IQR 22.6-39.5, } \\
\text { pre-conception) } \\
27.8 \text { (IQR 17.9-39.2, } \\
\text { non-FA) }\end{array}$ & $\mathrm{NR}$ \\
\hline Catov, 2011 & $\begin{array}{l}\text { Prospective } \\
\text { cohort, 1997- } \\
\text { 2003, Denmark }\end{array}$ & $\begin{array}{l}35897 \text { pregnant women in the Danish National } \\
\text { Birth Cohort }\end{array}$ & $\begin{array}{l}\text { pre-conception } \\
\text { or post- } \\
\text { conception }\end{array}$ & $\begin{array}{l}\text { Vit-FA: most } \\
\text { FA0.2mg/day }\end{array}$ & $\begin{array}{l}10.7 \text { (SD } \\
3.5, \text { FA) } \\
10.9 \text { (SD 3.8, } \\
\text { Vit-FA) } \\
11.4 \text { (SD } \\
4.3, \text { non-FA) }\end{array}$ & NR & NR \\
\hline Catov, 2009 & $\begin{array}{l}\text { Prospective } \\
\text { cohort, 1997- } \\
\text { 2003, Denmark }\end{array}$ & $\begin{array}{l}28601 \text { pregnant women in the Danish National } \\
\text { Birth Cohort }\end{array}$ & $\begin{array}{l}\text { pre-conception } \\
\text { or post- } \\
\text { conception }\end{array}$ & $\begin{array}{l}\text { FA: } 0.4 \mathrm{mg} / \text { day } \\
\text { Vit-FA: most } \\
\text { FA } 0.2 \mathrm{mg} / \text { day }\end{array}$ & $\begin{array}{l}10.8 \text { (SD } \\
3.4, \text { FA) } \\
10.9 \text { (SD } 3.5 \\
\text { Vit-FA) } \\
11.2 \text { (SD } \\
3.8, \text { non-FA) }\end{array}$ & NR & NR \\
\hline $\begin{array}{l}\text { Bukowski, } \\
2009\end{array}$ & $\begin{array}{l}\text { Prospective } \\
\text { cohort, 1999- } \\
\text { 2002, USA }\end{array}$ & $\begin{array}{l}34480 \text { women who delivered singleton } \\
\text { pregnancies with a gestational age of } 10 \text { week } 3 \mathrm{~d} \\
\text { through } 13 \text { week } 6 \mathrm{~d}\end{array}$ & pre-conception & NR & NR & $\begin{array}{l}27.8 \text { (IQR 23.5- } \\
32.5 \text {,non-FA) } \\
31.1 \text { (IQR 27.1- } \\
34.5,<1 \text { year) } \\
33.1 \text { (IQR29.4- } \\
36.3,>1 \text { year) }\end{array}$ & NR \\
\hline Wen, 2008 & $\begin{array}{l}\text { Prospective } \\
\text { cohort, 2002- } \\
\text { 2005, Canada }\end{array}$ & $\begin{array}{l}2951 \text { pregnant women with prenatal care visit } \\
\text { (12-20 weeks' gestation) at the Ottawa Hospital } \\
\text { and Kingston General Hospital }\end{array}$ & $\begin{array}{l}\text { pre-conception } \\
\text { or post- } \\
\text { conception }\end{array}$ & $\begin{array}{l}\text { most } 1.0 \mathrm{mg} \text { or } \\
\text { higher }\end{array}$ & NR & $\mathrm{NR}$ & NR \\
\hline Oken, 2007 & $\begin{array}{l}\text { Prospective } \\
\text { cohort, 1999- } \\
\text { 2002, USA }\end{array}$ & 1718 participants with live births in Project Viva & NR & $\begin{array}{l}\text { normal women: } \\
0.952 \text { (SD } \\
0.467) \mathrm{mg} \\
\text { PE: } 0.854(\mathrm{SD} \\
0.297) \mathrm{mg} \\
\text { GH: } 1.019 \text { (SD } \\
0.486) \mathrm{mg}\end{array}$ & 10.4 & NR & Table 1 continu \\
\hline
\end{tabular}




\begin{tabular}{|c|c|c|c|c|c|c|c|}
\hline Bodnar, 2006 & $\begin{array}{l}\text { Prospective } \\
\text { cohort, 1997- } \\
\text { 2001, USA }\end{array}$ & $\begin{array}{l}1835 \text { women aged } 14-44 \text { years, carrying } \\
\text { singleton infants, and planning to deliver at } \\
\text { Magee-Womens Hospital }\end{array}$ & NR & NR & NR & NR & NR \\
\hline Charles, 2005 & $\begin{array}{l}\text { Randomized } \\
\text { Controlled Trial, } \\
\text { 1996-1967, UK }\end{array}$ & $\begin{array}{l}2928 \text { pregnant women with live and stillborn } \\
\text { singletons in Aberdeen City }\end{array}$ & post-conception & $\begin{array}{l}\text { LD: } 0.2 \mathrm{mg} / \text { day } \\
\text { HD:5mg/day }\end{array}$ & $\begin{array}{l}17.5 \text { (SD } \\
5.3, \text { non-FA) } \\
16.9 \text { (SD } \\
4.8, \text { LD-FA) } \\
17.7 \text { (SD } \\
5.6, \text { HD-FA) }\end{array}$ & $\begin{array}{l}26.0 \text { (SD 5.6,non- } \\
\text { FA) } \\
25.8 \text { (SD 5.5,LD- } \\
\text { FA) } \\
25.5 \text { (SD 5.2,HD- } \\
\text { FA) }\end{array}$ & NR \\
\hline $\begin{array}{l}\text { Hernández- } \\
\text { Díaz, } 2002\end{array}$ & $\begin{array}{l}\text { Retrospective } \\
\text { cohort, 1993- } \\
\text { 2000, USA }\end{array}$ & $\begin{array}{l}2100 \text { women with nonmalformed infants who did } \\
\text { not have chronic hypertension of the Slone } \\
\text { Epidemiology Center }\end{array}$ & $\begin{array}{l}\text { pre-conception } \\
\text { or post- } \\
\text { conception }\end{array}$ & at least $0.4 \mathrm{mg}$ & NR & NR & $23.9(\mathrm{SD} 4.7)$ \\
\hline
\end{tabular}

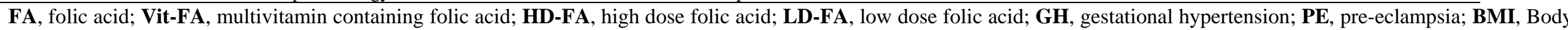
Mass Index; IQR, interquartile range; SD, standard deviation; NR, not reported.

Table 2. The clinical outcomes of included studies

\begin{tabular}{|c|c|c|c|c|c|c|c|}
\hline Author, year & Outcome-GH/PE & FA (n) & $\begin{array}{l}\text { FA-GH/PE } \\
\text { (n) }\end{array}$ & non-FA (n) & $\begin{array}{l}\text { non-FA- } \\
\text { GH/PE (n) }\end{array}$ & $\begin{array}{l}\text { FA-GH/PE risk } \\
\text { RR/OR/HR-95\% CI }\end{array}$ & Adjusted for \\
\hline $\mathrm{Li}, 2020$ & $\begin{array}{l}\text { GH-FA800-pre-conception } \\
\text { PE-FA800-pre-conception } \\
\text { GH-FA400-pre-conception } \\
\text { PE-FA400-pre-conception } \\
\text { GH-FA800-post-conception } \\
\text { PE-FA800-post-conception } \\
\text { GH-FA400-post-conception } \\
\text { PE-FA400-post-conception } \\
\end{array}$ & $\begin{array}{l}358 \\
358 \\
573 \\
573 \\
1504 \\
1504 \\
1772 \\
1772 \\
\end{array}$ & $\begin{array}{l}107 \\
17 \\
143 \\
19 \\
358 \\
50 \\
408 \\
57 \\
\end{array}$ & $\begin{array}{l}646 \\
646 \\
646 \\
646 \\
646 \\
646 \\
646 \\
646 \\
\end{array}$ & $\begin{array}{l}145 \\
18 \\
145 \\
18 \\
145 \\
18 \\
145 \\
18 \\
\end{array}$ & $\begin{array}{l}1.32(1.06-1.64) \\
1.45(0.74-2.83) \\
1.13(0.92-1.39) \\
1.29(0.66-2.51) \\
1.04(0.87-1.24) \\
1.03(0.59-1.79) \\
1.04(0.88-1.24) \\
1.25(0.72-2.18) \\
\end{array}$ & $\begin{array}{l}\text { age, education, work status, monthly income, } \\
\text { ethnicity, history of abnormal pregnancy, pre- } \\
\text { conception BMI, smoking, drinking, family } \\
\text { history of diabetes mellitus, family history of } \\
\text { hypertension, other supplement use, gestational } \\
\text { diabetes mellitus, and gestational weight gain }\end{array}$ \\
\hline Corsi, 2020 & PE & 215 & 37 & 213 & 21 & $1.58(0.95-2.63)$ & $\begin{array}{l}\text { age, smoking, parity, country, use of aspirin, } \\
\text { and history of preeclampsia }\end{array}$ \\
\hline Wen, 2018 & $\mathrm{PE}$ & 1174 & 169 & 1157 & 156 & $1.10(0.90-1.34)$ & parity, maternal age, and cigarette smoking \\
\hline Ocampo, 2017 & $\begin{array}{l}\text { GH-pre-conception } \\
\text { PE-pre-conception } \\
\text { GH-post-conception } \\
\text { PE-post-conception }\end{array}$ & $\begin{array}{l}2697 \\
2697 \\
471 \\
471\end{array}$ & $\begin{array}{l}95 \\
94 \\
14 \\
29\end{array}$ & $\begin{array}{l}79 \\
79 \\
79 \\
79\end{array}$ & $\begin{array}{l}3 \\
6 \\
3 \\
6\end{array}$ & $\begin{array}{l}0.91(0.27-3.05) \\
0.42(0.17-1.05) \\
0.76(0.21-2.83) \\
0.55(0.21-1.46)\end{array}$ & $\begin{array}{l}\text { education, race/ethnicity, parity, pre-conception } \\
\text { BMI, diabetes status, asthma status, } \\
\text { autoimmune disease status, cigarettes smoked } \\
\text { per day, maternal age, gravidity, previous } \\
\text { spontaneous abortion or stillbirth, } \\
\text { antidepressant use, cohort study and enrollment } \\
\text { year } \\
\text { Table } 2 \text { continues... }\end{array}$ \\
\hline
\end{tabular}


J Pharm Pharm Sci (www.cspsCanada.org) 24, 174 - 190, 2021

\begin{tabular}{|c|c|c|c|c|c|c|c|}
\hline \multirow[t]{4}{*}{ Wen, 2016} & PE-FA & 625 & 24 & 404 & 17 & $0.76(0.36-1.62)$ & \multirow{4}{*}{$\begin{array}{l}\text { maternal age, previous health problem (chronic } \\
\text { hypertension, history of preeclampsia, } \\
\text { diabetes), smoking, and parity }\end{array}$} \\
\hline & PE- Vit-FA +FA & 7265 & 228 & 404 & 17 & $0.58(0.33-1.02)$ & \\
\hline & PE-pre-conception & 3034 & 96 & 404 & 17 & $0.75(0.45-1.25)$ & \\
\hline & PE-post-conception & 4018 & 127 & 404 & 17 & $0.75(0.46-1.23)$ & \\
\hline Liu, 2015 & $\mathrm{PE}$ & 7864 & 206 & 2315 & 109 & $0.56(0.44-0.70)$ & NR \\
\hline \multirow[t]{3}{*}{ Wang, 2015} & $\mathrm{PE}$ & 794 & 238 & 265 & 115 & $0.61(0.43-0.87)$ & \multirow{3}{*}{$\begin{array}{l}\text { maternal age, education level, parity, maternal } \\
\text { diabetes, pre-conception BMI, weight gain } \\
\text { during pregnancy, family monthly income per } \\
\text { capita, multiple birth, maternal employment } \\
\text { during pregnancy, history of gestational } \\
\text { hypertension and dietary folate intake }\end{array}$} \\
\hline & PE-pre-conception & 306 & 97 & 265 & 115 & $0.64(0.42-0.98)$ & \\
\hline & PE-post-conception & 450 & 130 & 265 & 115 & $0.59(0.41-0.85)$ & \\
\hline \multirow{6}{*}{$\begin{array}{l}\text { Martinussen, } \\
2015\end{array}$} & PE-pre-conception & 1590 & NR & 2057 & NR & $0.80(0.60-1.20)$ & \multirow{6}{*}{$\begin{array}{l}\text { study (AIP or NIP), maternal age, maternal } \\
\text { ethnicity, maternal education, maternal marital } \\
\text { status, parity, maternal smoking in pregnancy } \\
\text { and any miscarriages or stillbirths in previous } \\
\text { pregnancies }\end{array}$} \\
\hline & PE-post-conception & 3301 & NR & 346 & NR & $1.10(0.60-2.10)$ & \\
\hline & BMI<25-PE-pre-conception & & & & & $0.60(0.40-1.00)$ & \\
\hline & BMI<25-PE-post-conception & NR & NR & NR & NR & $1.00(0.50-2.00)$ & \\
\hline & BMI>25-PE-pre-conception & NR & NR & NR & NR & $1.00(0.50-2.00)$ & \\
\hline & BMI>25-PE-post-conception & NR & NR & NR & NR & $1.40(0.50-3.50)$ & \\
\hline Kim, 2014 & $\mathrm{PE}$ & 134 & 6 & 81 & 12 & $0.27(0.09-0.76)$ & $\begin{array}{l}\text { parity, familial monthly income, preeclampsia } \\
\text { and prenatal intake of folic acid }\end{array}$ \\
\hline \multirow{6}{*}{$\begin{array}{l}\text { Vanderlelie, } \\
2014\end{array}$} & PE-FA & 476 & 6 & 1066 & 31 & $0.33(0.14-0.75)$ & \multirow{6}{*}{$\begin{array}{l}\text { maternal age, parity, gestational diabetes, } \\
\text { indigenous status and maternal smoking }\end{array}$} \\
\hline & PE- Vit-FA & 719 & 7 & 1066 & 31 & $0.42(0.13-0.98)$ & \\
\hline & BMI $<25-\mathrm{PE}-\mathrm{FA}$ & 283 & 4 & 616 & 12 & $0.72(0.39-1.35)$ & \\
\hline & BMI $<25-P E-$ Vit-FA & 406 & 4 & 616 & 12 & $0.60(0.39-1.36)$ & \\
\hline & $\mathrm{BMI}>25-\mathrm{PE}-\mathrm{FA}$ & 193 & 5 & 450 & 21 & $0.55(0.31-0.96)$ & \\
\hline & BMI>25-PE- Vit-FA & 313 & 3 & 450 & 21 & $0.48(0.27-0.86)$ & \\
\hline \multirow[t]{2}{*}{$\mathrm{Li}, 2013$} & $\mathrm{GH}$ & 32919 & 3226 & 100823 & 9477 & $1.09(1.04-1.14)$ & \multirow{2}{*}{$\begin{array}{l}\text { age (continuous), body mass index } \\
\text { (continuous), education, occupation, parity, and } \\
\text { multiple births }\end{array}$} \\
\hline & PE & 32919 & 888 & 100823 & 2420 & $1.21(1.11-1.31)$ & \\
\hline \multirow{4}{*}{$\begin{array}{l}\text { Timmermans, } \\
2011\end{array}$} & GH-pre-conception & 2362 & 165 & 1770 & 48 & $1.10(0.70-1.70)$ & \multirow{4}{*}{$\begin{array}{l}\text { gestational age, age, BMI, parity, ethnicity, } \\
\text { education, smoking, alcohol consumption, } \\
\text { antenatal care }\end{array}$} \\
\hline & GH-post-conception & 1861 & 87 & 1770 & 48 & $1.40(0.90-2.10)$ & \\
\hline & PE-pre-conception & 2362 & 45 & 1770 & 39 & $0.80(0.50-1.40)$ & \\
\hline & PE-post-conception & 1861 & 41 & 1770 & 39 & $0.90(0.50-1.30)$ & \\
\hline \multirow[t]{2}{*}{ Catov, 2011} & PE-FA & 2609 & 65 & 11503 & 265 & $1.08(0.83-1.41)$ & \multirow[t]{2}{*}{ NR } \\
\hline & PE-Vit-FA & 21789 & 479 & 11503 & 265 & $0.95(0.82-1.11)$ & \\
\hline \multirow[t]{6}{*}{ Catov, 2009} & PE-pre-conception- Vit-FA & 6655 & NR & 7582 & NR & $0.88(0.70-1.10)$ & \multirow{6}{*}{$\begin{array}{l}\text { body mass index, smoking, parity, chronic } \\
\text { hypertension, gestational age at recruitment, } \\
\text { and partial multivitamin use }\end{array}$} \\
\hline & PE-post-conception- Vit-FA & 3666 & NR & 7582 & NR & $0.74(0.56-0.98)$ & \\
\hline & PE-pre-conception-FA & $\mathrm{NR}$ & NR & NR & NR & $0.98(0.50-1.92)$ & \\
\hline & PE-post-conception-FA & NR & NR & NR & NR & $0.95(0.55-1.66)$ & \\
\hline & BMI<25-PE-pre-conception-Vit-FA & NR & NR & NR & NR & $0.78(0.57-1.06)$ & \\
\hline & BMI $<25$-PE-post-conception-Vit-FA & NR & NR & NR & NR & $0.63(0.42-0.93)$ & \\
\hline
\end{tabular}


J Pharm Pharm Sci (www.cspsCanada.org) 24, 174 - 190, 2021

\begin{tabular}{|c|c|c|c|c|c|c|c|}
\hline & BMI>25-PE-pre-conception-Vit-FA & NR & NR & NR & NR & $0.98(0.71-1.36)$ & \multirow{4}{*}{$\begin{array}{l}\text { maternal age, body mass index, race and } \\
\text { ethnicity, educational level, marital status, } \\
\text { smoking, parity and history of prior preterm } \\
\text { birth }\end{array}$} \\
\hline & BMI>25-PE-post-conception-Vit-FA & NR & NR & NR & NR & $0.98(0.59-1.30)$ & \\
\hline \multirow[t]{2}{*}{ Bukowski, 2009} & PE-pre-conception<1year & 12444 & 295 & 15259 & 381 & $1.03(0.86-1.23)$ & \\
\hline & PE-pre-conception>1year & 6777 & 157 & 15259 & 381 & $1.05(0.85-1.31)$ & \\
\hline \multirow[t]{4}{*}{ Wen, 2008} & PE-Vit-FA+FA & 2713 & 59 & 238 & 12 & $0.37(0.18-0.75)$ & \multirow{4}{*}{$\begin{array}{l}\text { maternal age, ethnic background, educational } \\
\text { level, parity, previous preeclampsia, chronic } \\
\text { hypertension, diabetes, pre-conception body } \\
\text { mass index, household income, gestational age } \\
\text { at recruitment, and cigarette smoking during } \\
\text { pregnancy }\end{array}$} \\
\hline & PE-FA & 421 & 12 & 238 & 12 & $0.46(0.16-1.31)$ & \\
\hline & PE-pre-conception & 1031 & 24 & 238 & 12 & $0.46(0.23-0.91)$ & \\
\hline & PE-post-conception & 1682 & 35 & 238 & 12 & $0.41(0.22-0.78)$ & \\
\hline \multirow[t]{2}{*}{ Oken, 2007} & GH & NR & NR & NR & NR & $1.02(0.99-1.06)$ & \multirow{2}{*}{$\begin{array}{l}\text { maternal age }(<20,20-<40,40+\text { years }), \text { pre- } \\
\text { conception body mass index (continuous), first- } \\
\text { trimester systolic blood pressure (continuous), } \\
\text { race/ethnicity (black, Hispanic, white, other), } \\
\text { education (college graduate, }<\text { College } \\
\text { graduate), and parity }(0,1+)\end{array}$} \\
\hline & $\mathrm{PE}$ & NR & NR & NR & NR & $0.96(0.89-1.03)$ & \\
\hline \multirow[t]{3}{*}{ Bodnar, 2006} & PE-Vit-FA & 860 & 33 & 975 & 43 & $0.55(0.32-0.95)$ & \multirow{3}{*}{$\begin{array}{l}\text { race (Black, other), marital status (married, } \\
\text { unmarried), parity (primiparous, multiparous), } \\
\text { pre-conceptional physical activity (yes, no), and } \\
\text { poverty index ratio }(130 \%, 131-299 \%, 300 \%)\end{array}$} \\
\hline & BMI<25-PE- Vit-FA & 860 & 21 & 975 & 42 & $0.29(0.12-0.65)$ & \\
\hline & BMI>25-PE- Vit-FA & 860 & 53 & 975 & 45 & $1.08(0.52-2.25)$ & \\
\hline \multirow[t]{2}{*}{ Charles, 2005} & PE-LD & 448 & 8 & 1890 & 51 & $0.46(0.20-1.05)$ & \multirow{2}{*}{$\begin{array}{l}\text { smoking at booking, social class, parity, } \\
\text { gestation at booking, height of women, weight } \\
\text { of women at booking and gestation at delivery }\end{array}$} \\
\hline & PE-HD & 459 & 7 & 1890 & 51 & $0.59(0.26-1.32)$ & \\
\hline \multirow{3}{*}{$\begin{array}{l}\text { Hernández-Díaz, } \\
2002\end{array}$} & GH & NR & NR & NR & NR & $0.53(0.36-0.80)$ & \multirow{3}{*}{$\begin{array}{l}\text { geographic region, family income, and maternal } \\
\text { age, pre-conception weight, parity, twin } \\
\text { pregnancy, diabetes, smoking, and education }\end{array}$} \\
\hline & $\mathrm{PE}$ & NR & NR & NR & NR & $0.63(0.28-1.45)$ & \\
\hline & GH-pre-conception & NR & NR & NR & NR & $0.61(0.37-1.00)$ & \\
\hline
\end{tabular}

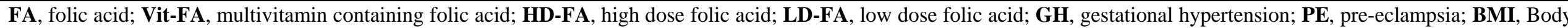
Mass Index; HR, hazard ratio; OR, odds ratio; RR, relative risk; CI, confidence interval; NR, not reported 
may be most effective to prevent PE which was consistent with our finding that post-conception FA could reduce the risk of $\mathrm{PE}$ rather than preconception FA (22). It should be noted that preconception FA is a necessary measure to prevent neural tube defects (NTDs). Therefore, it is a more clinically appropriate choice to extend the use of FA into the later trimesters rather than starting it after pregnancy.

Another finding from our analysis was that FA supplementation could have a significant protective effect among women with pre-conception $\mathrm{BMI}<25$ $\mathrm{kg} / \mathrm{m}^{2}$ but not statistically significant among overweight women (pre-conception BMI $\geq 25 \mathrm{~kg} / \mathrm{m}^{2}$ ). Firstly, the pathogenic mechanisms of PE may be different among women with $\mathrm{BMI}<25 \mathrm{~kg} / \mathrm{m}^{2}$ and BMI $\geq 25 \mathrm{~kg} / \mathrm{m}^{2}$. The excess risk of PE might be associated with overweight or even obese status. Additionally, most pregnant women take low dose of FA, but both FA alone and multivitamin may not be adequate to overcome the metabolic disturbances of overweight or obese status $(7,11)$.

Our meta-analysis had several advantages. First, RCTs of HD-FA supplementation were analyzed separately from LD-FA to avoid bias, as the relationship between HD-FA and PE is still controversial. In addition, we did the subgroup analysis and the results demonstrated that postconception LD-FA and pre-conception $\mathrm{BMI}<25$ $\mathrm{kg} / \mathrm{m}^{2}$ were protective factors for pregnant women. We also acknowledged some limitations in this study. First, it has been recommended for women planning pregnancy to use FA until the third month of pregnancy to prevent NTDs. However, the discontinued time of FA is unclear for the pregnant women included in this study, particularly preconception FA. Therefore, the association of postconception FA and the decreased risk of PE need to be further confirmed. Secondly, most studies included in this study did not consider the effects of serum FA and serum Hcy. Meanwhile, the genotype of MTHFR was not considered in most studies but it was also an important factor because the studies included came from different countries. And it was difficult to accurately evaluate the dose of dietary FA, which could cause the bias of final results. In addition, although the result indicated that Vit-FA might be more meaningful than FA alone to reduce the risk of PE, it was hard to further compare the effects of FA with Vit-FA due to the few clinical studies. Lastly, only few studies have been conducted in pregnant women with high-risk (20, 22-23). Thus, we need more high-quality clinical studies to confirm the findings of this study, such as detailed documentation for FA dose, start and end time, form of FA, high-risk factors, and detection of genotype of MTHFR and serum FA.

\section{CONCLUSIONS}

Our meta-analysis found that LD-FA tended to decrease the risk of PE. In addition, post-conception LD-FA and pre-conception $\mathrm{BMI}<25 \mathrm{~kg} / \mathrm{m}^{2}$ were considered as protective factors to reduce the risk of PE. Therefore, we recommend that pregnant women use LD-FA throughout the pregnancy period to avoid the occurrence of PE. More importantly, a more convincing result require the inclusion of more rigorous RCTs.

\section{FUNDING}

This study was not funded by any organizations.

\section{CONFLICT OF INTEREST}

The authors declare that they have no known competing financial interests or personal relationships that could have appeared to influence the work reported in this paper.

\section{REFERENCES}

1. WHO Recommendations for Prevention and Treatment of Pre-Eclampsia and Eclampsia. Geneva: World Health Organization; 2011.

2. Butalia S, Audibert F, Côté AM, et al. Hypertension Canada's 2018 Guidelines for the Management of Hypertension in Pregnancy. Can J Cardiol. 2018;34(5):526-531. doi:10.1016/j.cjca.2018.02.021

3. American College of Obstetricians and Gynecologists' Committee on Practice Bulletins-Obstetrics. Gestational Hypertension and Preeclampsia: ACOG Practice Bulletin, Number 222. Obstet Gynecol. 2020;135(6):e237-e260. doi:10.1097/AOG.0000000000003891

4. Li Y, Huang T, Zheng Y, Muka T, Troup J, Hu FB. Folic Acid Supplementation and the Risk of Cardiovascular Diseases: A Meta-Analysis of Randomized Controlled Trials. J Am Heart Assoc. 2016;5(8):e003768. Published 2016 Aug 15. doi:10.1161/JAHA.116.003768

5. Hernández-Díaz S, Werler MM, Louik C, Mitchell AA. Risk of gestational hypertension in relation to folic acid supplementation during pregnancy. Am J Epidemiol. 2002;156(9):806812. doi:10.1093/aje/kwf129

6. Charles DH, Ness AR, Campbell D, Smith GD, Whitley E, Hall MH. Folic acid supplements in pregnancy and birth outcome: re-analysis of a 
large randomised controlled trial and update of Cochrane review. Paediatr Perinat Epidemiol. 2005;19(2):112-124. doi:10.1111/j.13653016.2005.00633.x

7. Bodnar LM, Tang G, Ness RB, Harger G, Roberts JM. Periconceptional multivitamin use reduces the risk of preeclampsia. Am J Epidemiol. doi:10.1093/aje/kwj218

8. Oken E, Ning Y, Rifas-Shiman SL, RichEdwards JW, Olsen SF, Gillman MW. Diet during pregnancy and risk of preeclampsia or gestational hypertension. Ann Epidemiol. 2007;17(9):663-668.

doi:10.1016/j.annepidem.2007.03.003

9. Wen SW, Chen XK, Rodger M, et al. Folic acid supplementation in early second trimester and the risk of preeclampsia. Am J Obstet Gynecol. 2008;198(1):45.e1-45.e457. doi:10.1016/j.ajog.2007.06.067

10. Bukowski R, Malone FD, Porter FT, et al. Preconceptional folate supplementation and the risk of spontaneous preterm birth: a cohort study. PLoS Med. 2009;6(5):e1000061. doi:10.1371/journal.pmed.1000061

11. Catov JM, Nohr EA, Bodnar LM, Knudson VK, Olsen SF, Olsen J. Association of periconceptional multivitamin use with reduced risk of preeclampsia among normal-weight women in the Danish National Birth Cohort. Am J Epidemiol. 2009;169(11):1304-1311. doi:10.1093/aje/kwp052

12. Catov JM, Bodnar LM, Olsen J, Olsen S, Nohr EA. Periconceptional multivitamin use and risk of preterm or small-for-gestational-age births in the Danish National Birth Cohort. Am J Clin Nutr. 2011;94(3):906-912. doi:10.3945/ajen.111.012393

13. Timmermans S, Jaddoe VW, Silva LM, et al. Folic acid is positively associated with uteroplacental vascular resistance: the Generation R study. Nutr Metab Cardiovasc Dis. 2011;21(1):54-61. doi:10.1016/j.numecd.2009.07.002

14. Li Z, Ye R, Zhang L, Li H, Liu J, Ren A. Folic acid supplementation during early pregnancy and the risk of gestational hypertension and preeclampsia. Hypertension. 2013;61(4):873879.

doi:10.1161/HYPERTENSIONAHA.111.0023 0

15. Kim MW, Ahn KH, Ryu KJ, et al. Preventive effects of folic acid supplementation on adverse maternal and fetal outcomes. PLoS One. 2014;9(5):e97273. Published 2014 May 19. doi:10.1371/journal.pone.0097273

16. Vanderlelie J, Scott R, Shibl R, Lewkowicz J, Perkins A, Scuffham PA. First trimester multivitamin/mineral use is associated with reduced risk of pre-eclampsia among overweight and obese women. Matern Child Nutr. 2016;12(2):339-348. doi: $10.1111 / \mathrm{mcn} .12133$

17. Liu $X, L v$ L, Zhang $H$, et al. Folic acid supplementation, dietary folate intake and risk of preterm birth in China. Eur $\mathbf{J}$ Nutr. 2016;55(4):1411-1422. doi:10.1007/s00394015-0959-1

18. Martinussen MP, Bracken MB, Triche EW, Jacobsen GW, Risnes KR. Folic acid supplementation in early pregnancy and the risk of preeclampsia, small for gestational age offspring and preterm delivery. Eur J Obstet Gynecol Reprod Biol. 2015;195:94-99. doi:10.1016/j.ejogrb.2015.09.022

19. Wang Y, Zhao N, Qiu J, et al. Folic acid supplementation and dietary folate intake, and risk of preeclampsia. Eur J Clin Nutr. 2015;69(10):1145-1150.

doi:10.1038/ejen.2014.295

20. Wen SW, Guo Y, Rodger M, et al. Folic Acid Supplementation in Pregnancy and the Risk of Pre-Eclampsia-A Cohort Study. PLoS One. 2016;11(2):e0149818. Published 2016 Feb 22. doi:10.1371/journal.pone.0149818

21. De Ocampo MPG, Araneta MRG, Macera CA, Alcaraz JE, Moore TR, Chambers CD. Folic acid supplement use and the risk of gestational hypertension and preeclampsia. Women Birth. 2018;31(2):e77-e83. doi:10.1016/j.wombi.2017.08.128

22. Wen SW, White RR, Rybak N, et al. Effect of high dose folic acid supplementation in pregnancy on pre-eclampsia (FACT): double blind, phase III, randomised controlled, international, multicentre trial. BMJ. 2018;362:k3478. Published 2018 Sep 12. doi:10.1136/bmj.k3478

23. Corsi DJ, Gaudet LM, El-Chaar D, et al. Effect of high-dose folic acid supplementation on the prevention of preeclampsia in twin pregnancy [published online ahead of print, $2020 \mathrm{Feb} 18$ ]. J Matern Fetal Neonatal Med. 2020;1-6. doi:10.1080/14767058.2020.1725882

24. Li Q, Xu S, Chen X, et al. Folic Acid Supplement Use and Increased Risk of Gestational Hypertension. Hypertension. 2020;76(1):150-156. 
doi:10.1161/HYPERTENSIONAHA.119.1462 1

25. Zheng L, Huang J, Kong H, Wang F, Su Y, Xin $H$. The effect of folic acid throughout pregnancy among pregnant women at high risk of pre-eclampsia: A randomized clinical trial. Pregnancy Hypertens. 2020;19:253-258. doi:10.1016/j.preghy.2020.01.005

26. Chen S, Li N, Mei Z, et al. Micronutrient supplementation during pregnancy and the risk of pregnancy-induced hypertension: A randomized clinical trial. Clin Nutr. 2019;38(1):146-151. doi:10.1016/j.clnu.2018.01.029

27. Shahraki AD, Dehkordi NZ, Lotfizadeh M. Comparison of high dose and low dose folic acid supplementation on prevalence, onset and severity of preeclampsia. Adv Biomed Res. 2016;5:192. Published 2016 Dec 27. doi:10.4103/2277-9175.190944

28. Hua X, Zhang J, Guo Y, et al. Effect of folic acid supplementation during pregnancy on gestational hypertension/preeclampsia: A systematic review and meta-analysis. Hypertens Pregnancy. 2016;35(4):447-460. doi:10.1080/10641955.2016.1183673

29. Shim SM, Yun YU, Kim YS. Folic acid alone or multivitamin containing folic acid intake during pregnancy and the risk of gestational hypertension and preeclampsia through metaanalyses. Obstet Gynecol Sci. 2016;59(2):110115. doi:10.5468/ogs.2016.59.2.110

30. Yang X, Chen H, Du Y, Wang S, Wang Z. Periconceptional folic acid fortification for the risk of gestational hypertension and preeclampsia: a meta-analysis of prospective studies. Matern Child Nutr. 2016;12(4):669679. doi:10.1111/mcn.12209

31. Liu C, Liu C, Wang Q, Zhang Z. Supplementation of folic acid in pregnancy and the risk of preeclampsia and gestational hypertension: a meta-analysis. Arch Gynecol Obstet. 2018;298(4):697-704. doi:10.1007/s00404-018-4823-4

32. Bulloch RE, Lovell AL, Jordan VMB, McCowan LME, Thompson JMD, Wall CR. Maternal folic acid supplementation for the prevention of preeclampsia: A systematic review and meta-analysis. Paediatr Perinat Epidemiol. 2018;32(4):346-357. doi:10.1111/ppe.12476

33. Wen SW, Zhou J, Yang Q, Fraser W, Olatunbosun O, Walker M. Maternal exposure to folic acid antagonists and placenta-mediated adverse pregnancy outcomes. CMAJ.
2008;179(12):1263-1268.

doi:10.1503/cmaj.080859

34. Gaiday AN, Tussupkaliyev AB, Bermagambetova SK, et al. Effect of homocysteine on pregnancy: A systematic review. Chem Biol Interact. 2018;293:70-76. doi:10.1016/j.cbi.2018.07.021

35. Clarke R, Halsey J, Bennett D, Lewington S. Homocysteine and vascular disease: review of published results of the homocysteine-lowering trials. J Inherit Metab Dis. 2011;34(1):83-91. doi:10.1007/s10545-010-9235-y

36. Ganguly P, Alam SF. Role of homocysteine in the development of cardiovascular disease. Nutr J. 2015;14:6. Published 2015 Jan 10. doi:10.1186/1475-2891-14-6

37. Stanhewicz AE, Kenney WL. Role of folic acid in nitric oxide bioavailability and vascular endothelial function. Nutr Rev. 2017;75(1):6170. doi:10.1093/nutrit/nuw053 


\section{SUUPLIMETRARY DATA}

\section{Appendix 1}

\section{PUBMED : 251}

("vitamin b9"[Text Word] OR "folic acid"[Text Word]) AND (("preeclampsia"[Text Word] OR "pregnancy induced hypertension"[Text Word]) OR "gestational hypertension" [Text Word])

EMBASE: 950

$\begin{array}{lll}1 & \text { *folic acid/ or vitamin bg.mp. } & 23490 \\ 2 & \text { folic acid.mp. } & 77966 \\ & \text { *preeclampsia/ or } & 63544 \\ & \text { preeclampsia.mp. } & \\ 4 & \text { gestational hypertension.mp. or } & 9880 \\ & \text { *maternal hypertension/ } & \\ 5 & \text { pregnancy induced } & 5371 \\ 6 & \text { hypertension.mp. } & 3420 \\ & \text { hypertensive disorders of } & \\ 7 & \text { pregnancy.mp. } & 78075 \\ 8 & \text { 1 or 2 } & 70227 \\ 9 & \text { 3 or 4 or 5 or 6 } & 950\end{array}$

COCHRANE: 93

\#1 (vitamin b9) : ti, ab, kw

\#2 MeSH descriptor: [Folic Acid] this term only

\#3 (folic acid) : ti, ab, kw

\#4 (\#1) OR (\#2) OR (\#3)

\#5 MeSH descriptor: [Pre-Eclampsia] this term only

\#6 (preeclampsia) : ti, ab, kw

\#7 (pre-eclampsia) : ti, ab, kw

\#8 MeSH descriptor: [Hypertension, Pregnancy-Induced] this term only

\#9 (pregnancy induced hypertension) : ti, ab, kw

\#10 (gestational hypertension) : ti, ab, kw

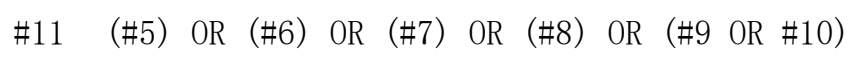

\#12 (\#11) AND (\#4) 
Appendix 2. Table A. Quality of observational studies (indicators from New-Castle-

Ottawa scale)

\begin{tabular}{|l|l|l|l|l|l|l|l|l|l|l|}
\hline study & $\mathbf{1}^{\mathbf{a}}$ & $\mathbf{2}^{\mathbf{b}}$ & $\mathbf{3}^{\mathbf{c}}$ & $\mathbf{4}^{\mathbf{d}}$ & $\mathbf{5 A}^{\mathbf{e}}$ & $\mathbf{5 B}^{\mathbf{f}}$ & $\mathbf{6}^{\mathbf{g}}$ & $\mathbf{7}^{\mathbf{h}}$ & $\begin{array}{l}\mathbf{8}^{\mathbf{i}} \\
\mathbf{q u a l i t y} \\
\text { scores }\end{array}$ \\
\hline Li, 2020 & Yes & Yes & Yes & Yes & Yes & Yes & Yes & Yes & Yes & 9 \\
\hline Ocampo, 2017 & Yes & Yes & Yes & Yes & Yes & Yes & Yes & Yes & Yes & 9 \\
\hline Wen, 2016 & Yes & Yes & No & Yes & Yes & Yes & Yes & Yes & Yes & 8 \\
\hline Liu, 2015 & Yes & Yes & Yes & Yes & No & No & Yes & Yes & Yes & 7 \\
\hline Wang, 2015 & Yes & Yes & Yes & Yes & Yes & Yes & Yes & Yes & Yes & 9 \\
\hline Martinussen, 2015 & Yes & Yes & Yes & Yes & Yes & Yes & Yes & Yes & Yes & 9 \\
\hline Kim, 2014 & Yes & Yes & No & Yes & Yes & Yes & Yes & Yes & Yes & 8 \\
\hline Vanderlelie, 2014 & Yes & Yes & Yes & Yes & Yes & Yes & Yes & Yes & Yes & 9 \\
\hline Li, 2013 & Yes & Yes & Yes & Yes & Yes & Yes & Yes & Yes & Yes & 9 \\
\hline Timmermans, 2011 & Yes & Yes & Yes & Yes & Yes & Yes & Yes & Yes & Yes & 9 \\
\hline Catov, 2011 & Yes & Yes & Yes & Yes & No & No & Yes & Yes & Yes & 7 \\
\hline Catov, 2009 & Yes & Yes & Yes & Yes & Yes & Yes & Yes & Yes & Yes & 9 \\
\hline Bukowski, 2009 & Yes & Yes & No & Yes & Yes & Yes & No & Yes & Yes & 7 \\
\hline Wen, 2008 & Yes & Yes & Yes & Yes & Yes & Yes & Yes & Yes & Yes & 9 \\
\hline Oken, 2007 & Yes & Yes & Yes & Yes & Yes & Yes & Yes & Yes & Yes & 9 \\
\hline Bodnar, 2006 & Yes & Yes & Yes & Yes & Yes & Yes & Yes & Yes & Yes & 9 \\
\hline Hernández-Díaz, 2002 & Yes & Yes & Yes & Yes & Yes & Yes & No & Yes & Yes & 8 \\
\hline
\end{tabular}

a: Indicates exposed cohort truly representative

b: Non-exposed cohort drawn from the same community

c: Ascertainment of exposure from the same community

$\mathrm{d}$ : Outcome of interest not present at start of study

e: Cohorts comparable on basis of site and etiology of infection

f: Cohorts comparable on others factors

$\mathrm{g}$ : Assessment of outcome of record linkage or independent blind assessment

h: Follow-up long enough for outcomes to occur

I: Complete accounting for cohort

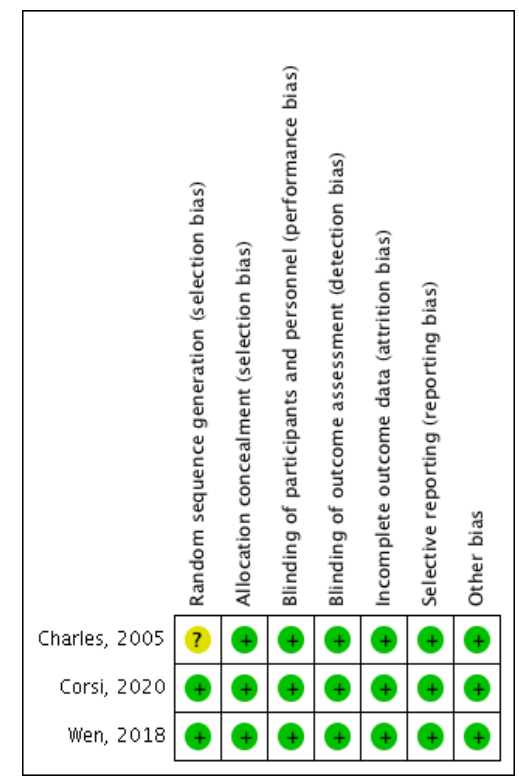

Appendix 3 Figure 1

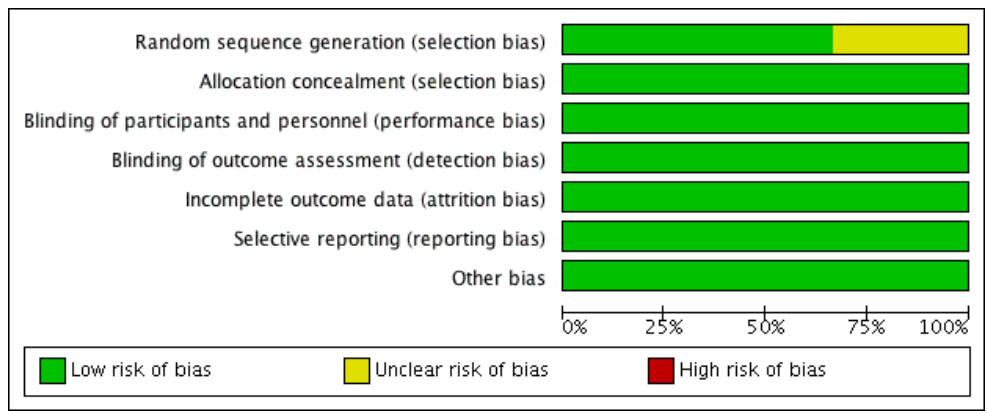

Appendix 3 Figure 2 


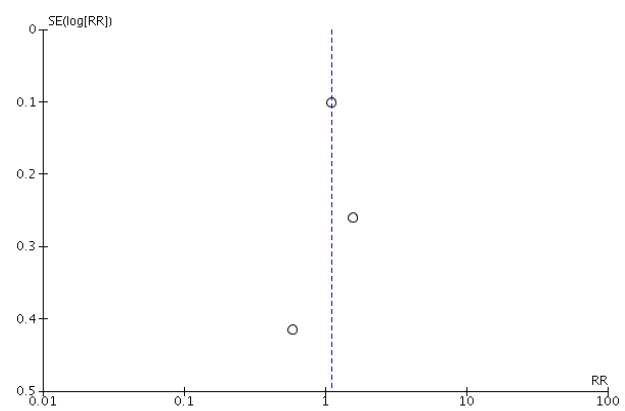

Appendix 4 Figure 1

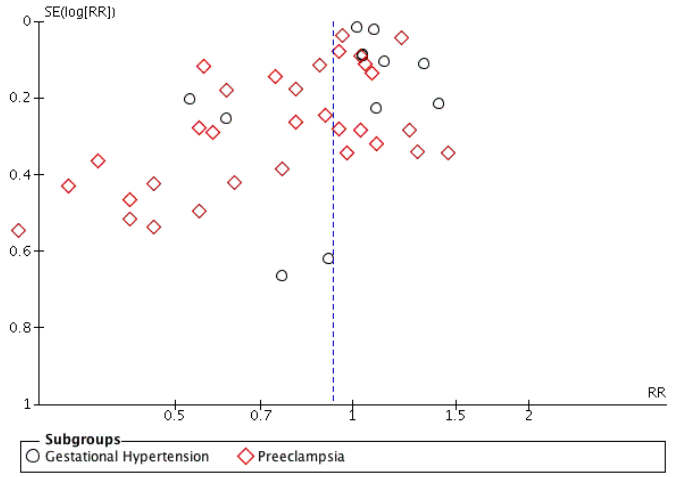

Appendix 4 Figure 2

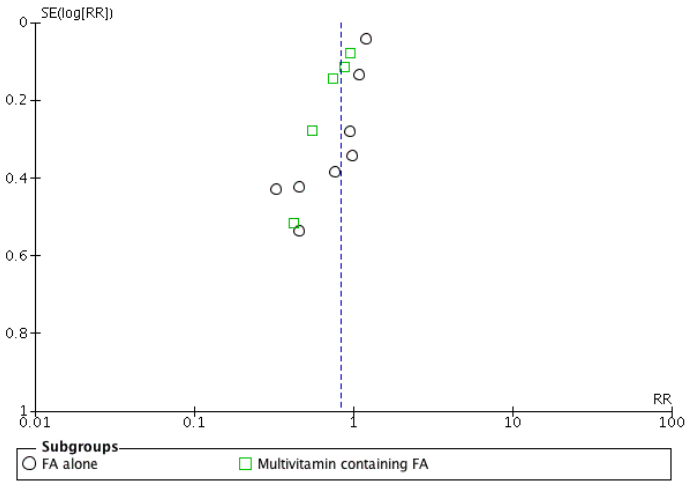

Appendix 4 Figure 3

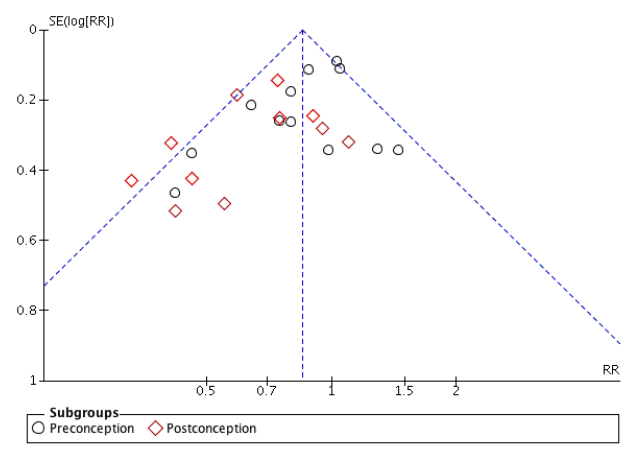

Appendix 4 Figure 4

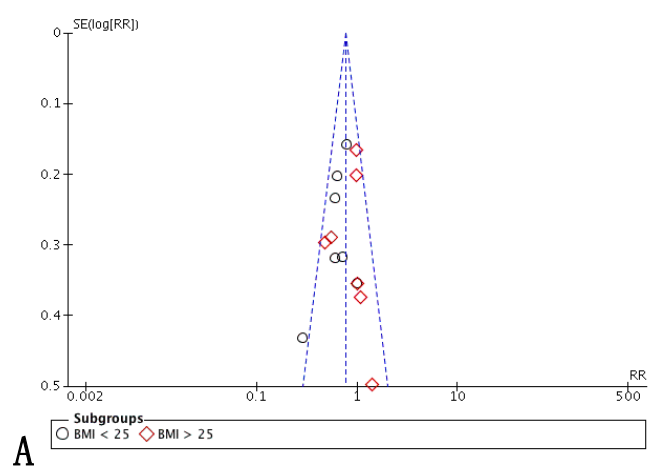

Appendix 4 Figure 5 
